\title{
Proverb și stil în publicistica lui Eminescu
}

\author{
Ioan Milică ${ }^{\circledR \star}$ \\ Facultatea de Litere, Universitatea „Alexandru Ioan Cuza”, Bd. Carol I 11, 700506 Iași, România
}

\section{Despre articol}

Istoric:

Primit 27 octombrie 2019

Acceptat 3 noiembrie 2019

Publicat 7 noiembrie 2019

Cuvinte-cheie:

lingvistica textului

analiză stilistică

scriere jurnalistică

Mihai Eminescu

\begin{abstract}
Rezumat
Articolul interoghează teza că Mihai Eminescu (1850-1889), cel mai important scriitor român din secolul al XIX-lea, a valorificat în scrierile sale jurnalistice eşantioane paremiologice culese din vorbirea oamenilor de rînd. În privinţa sutelor de proverbe prezente în articolele de presă redactate de Eminescu, îmi propun să arăt că scriitorul a naturalizat în mozaicul textelor gazetărești decupaje livrești cărora le-a conferit aparența stilistică a unor elemente populare. Fără a nega că unele dintre proverbele la care poetul recurge pe teren jurnalistic provin din limba comună, în studiul de faţă mă preocupă mizanscena orchestrată de scriitor pentru a conferi aură folclorică unor decupaje culte. Nu în ultimul rînd, cercetarea atrage atenția asupra disponibilității lui Eminescu de a experimenta formule de scriere jurnalistică dintre cele mai variate, rafinate în acord cu ideile, temperamentul și imaginația artistului.
\end{abstract}

\begin{abstract}
Motto: „quid, queso, probabilius quam quod nemo non dicit? Quid verisimilius, quam id, qoud tot atatum, tot nationum consensus et velut idem suffragium comprobauit?"

[„,e ar putea fi mai convingător, întreb, decît ceea ce zice toată lumea? Ce ar fi mai credibil decît ceea ce e stabilit prin consens, prin votul unanim al atîtor oameni din diverse timpuri?”]
\end{abstract}

(Erasmi Roterodami, Adagiorum chiliades tres, 1508)

\section{Preliminarii}

Știm astăzi că Eminescu a fost un spirit proverbial. Atenți la armoniile frazei gazetărești, comentatorii cu har, precum Perpessicius (1983, p. 411), s-au oprit asupra fascinației ritmice pe care au exercitat-o proverbele asupra simțului muzical al poetului, arătînd că suitele de vorbe înțelepte pe care Eminescu le valorifică în unele articole au fond estetic, în sensul că oglindesc frumusețea unui univers literar popular căzut în uitare și pe care gazetarul îl restaurează. Alții, mai speculativi, au subliniat atracția față de „plasticitatea proverbelor” ca dovadă a interesului „teoretic și practic” față de tezaurul paremiologic (Eminescu, 1980, p. 44; Oprea, 1983, p. 99). Din acest punct de vedere, Eminescu ar fi fost, ca și Creangă, un harnic explorator al filonului folcloric.

Aparent convingătoare, aprecierile axate asupra rezonanțelor estetice, retorice și pragmatice ale proverbelor fructificate în publicistica eminesciană nu reconstituie, totuşi, cadrul în care scriitorul creează o poetică a proverbului. Pentru a scoate din umbră și din uitare acest tablou e necesar să ne apropiem de istoria culturală a proverbelor, dar, înainte de a urma acest drum, se cuvine să nuanțăm ideea că Eminescu ar fi fost culegător de proverbe. Fără a nega că scriitorul a strîns folclor, e mai important să observăm ce beneficii a adus creației eminesciene respectiva activitate. În loc să reluăm ponciful că poetul a adunat din gura poporului vorbe înțelepte pe care, mai apoi, le-a folosit în creația sa, e mai rodnică discutarea unor probe care lămuresc ce efecte a produs, asupra lui Eminescu, întîlnirea cu lumea enigmatică a proverbelor.

\footnotetext{
*Adresă de corespondență: ioanister@gmail.com.
} 


\section{Proverbialul Eminescu}

Prin 1868, își amintește Ștefan Cacoveanu, poetul, pe atunci sufleur la Teatrul Naţional din București, vorbea pilduitor despre riscurile debutului literar: „Pe unul dintre noi îl puse păcatele să-și tipărească versurile. Să fi văzut pe Eminescu cît haz făcea din aceasta. Versurile erau slăbuțe. [... ] Cu tonul lui de un timbru profund, dar dulce, cîteodată vorbea ca de pe catedră. Zicea: „A ieși în publicitate nu-i glumă. Mai de multe ori îmi pare rău c-am publicat ceea ce am publicat. Este o zicală din bătrîni: «Gura să aibă trei lacăte: în inimă, în gît și a treia pe buze: cînd îți va scăpa cuvîntul din inimă, să nu scape de cealaltă, că dacă ai scăpat o dată vorba din gură, n-o mai prinzi nici cu calul, nici cu ogarul, ba nici cu șoimul». Trebuie să cumpănești de-o sută de ori o scriere pînă o dai publicității” (Cioabă, 2013, p. 98).

Cel ce-și tipărise versurile era Ioniță Scipione Bădescu, unul din ardelenii din cercul de studenți de la Viena și viitor coleg de redacție cu Eminescu, iar „zicala din bătrîni” rostită „ca de pe catedră” nu era atît o vorbă țărănească, cît un decupaj din celebra carte populară Archirie şi Anadan, lucrare care circula în spațiul cultural românesc, încă din secolul al XVII-lea, fiind tipărită, prin grija lui Anton Pann ${ }^{1}$, în 1850: „Fătul mieu, cînd vei să grăiești cu domnu-tău, să aibă cuvîntul trei porți: o poartă la inimă, alta în grumazi, al treile în gură, și de-aciia să grăiești, că cuvintul, daca-l laș din gură, nu-l poți agiunge nice <cu > calul, nice cu ogarul, nice cu șoimul, ce, cîtu-l grăiești, așa treace” (Georgescu, 1997, p. 159). Nu e posibil să aflăm cu precizie dacă poetul va fi cules formula din vorbirea oamenilor simpli, fapt puțin plauzibil, dacă va fi reținut fragmentul din faimoasa narațiune orientală sau dacă i-a fost atribuită de către Ștefan Cacoveanu, scriitorul fiind, astfel, prefăcut într-un personaj cu nimic deosebit de eroii literari. Mai sigură decît astfel de presupuneri e observația că Pann (1963, II, p. 27) a imitat ${ }^{2}$ faimoasa poveste orientală în minunata sa culegere de proverburi, după cum se poate constata din fragmente ca acesta: „Cuvîntul e ca vîntul, nu să ajunge nici cu armăsarul, nici cu ogarul." Inclusă de Zanne în antologia intitulată Proverbele românilor (10 volume, 1895-1903), comparația rimată a lui Anton Pann a fost privită ca mostră de istețime țărănească, în ciuda evidentei sale origini culte, așa că editorii de mai apoi au inclus-o în culegerile de proverbe populare (Muntean, 1984, [2738], p. 104).

Certitudinea că Eminescu avea, totuși, harul de a se exprima proverbial o căpătăm și din altă sursă, Amintirile lui Theodor Ștefanelli. Acesta povestește că, în 1875, adică în anul în care, la Cernăuți, oficialitățile pregăteau centenarul „încorporării Bucovinei la Austria”, Eminescu sosi pe neașteptate în oraş, aducînd cu el mai multe sute de exemplare dintr-o broșură intitulată „Răpirea Bucovinei”, pe care le trecuse ilegal peste graniță, într-un „,ogeamite lădoi de lemn”, plin cu o „mulțime de cărți vechi, psaltiri, ceasloave, biblii” și „alte hîrțoage rupte”. Întrebat ce noimă are să care după sine o ditamai lada de tipărituri vechi, Eminescu replică, în germană, das beste kommt zuletzt, arătînd astfel că publicația subversivă fusese dosită sub mormanul de vechituri, spre a nu deștepta bănuielile vameșilor (Ștefanelli, 1914, p. 150). Cine rîde la urmă rîde mai bine, pare a transmite poetul vechiului său tovarăș de școală și nu putem trece cu vederea că recursul la proverbul german îi servește nu atît pentru a face o demonstrație de competență comunicativă în limba lui Goethe, cît pentru a semnala că textele paremiologice au darul de a dezvălui însemnătatea unui fapt de viață autentic. În fond, ele înfățișează lumea ca spectacol.

Scrisorile poetului reliefează, de asemenea, preferința ocazională pentru proverbe în care imaginea, rod al fanteziei, și gîndul dens, fruct al cugetării, se potențează reciproc. În vara anului 1882, redactorul

\footnotetext{
${ }^{1}$ În versiunea publicată de Pann (1963, III, p. 12), fragmentul e prelucrat: „Cînd vei vrea să vorbești cu cineva, să-ți scoți cuvîntul prin trei lacăte, adică: unul să-l aibi la inimă, al doilea la gît și al treilea la buze; că «dacă iese din gură cuvîntul, se duce iute ca vîntul; și nu-l poți ajunge nici cu armăsatul, nici cu ogarul»”.

${ }^{2}$ Textul cunoscut la români sub denumirea Archirie și Anadan are o istorie culturală cu origini străvechi, fiind subsumat literaturii sapiențiale orientale. În raport cu lunga și complicata tradiție manuscrisă a textului, tipograful Anton Pann și-a îngăduit libertăți editoriale dintre cele mai îndrăznețe, de la versificarea unor pasaje la ignorarea unor fragmente. Ca izvor literar, Archirie și Anadan a jucat un rol deloc neglijabil în cultura română a secolului al XIX-lea: „o bună parte din maximele lui Archirie au trecut în nuvela lui C. Negruzzi, Păcală și Tîndală. Anton Pann, care a prelucrat romanul lui Archirie, și-a sporit și el colecția de proverbe (Povestea vorbii) cu elemente împrumutate din Archirie; alte sentințe ale înțeleptului asirian își găsesc paralele interesante în colecția lui Zanne" (Cartojan, 1974, I, p. 323).
} 
„Timpului”, prins în infernul canicular al Bucureștilor, îi trimite Veronicăi Micle o epistolă în care se plînge de starea proastă pe care o resimte şi de neajunsul de a fi rămas singur să umple ziarul. De dragul partenerei, pe care o încurajează, gîndurile neguroase sînt alungate prin apel la un fond sapiențial familiar epistolierilor: „Eh! La pauvreté est une mauvaise chose! Și chip să scap de ea pentru totdeuna nu se vede încă. Dar în sfîrșit, bun e Dumnezeu și meșter e dracul. După ploaie trebuie să vie și senin, care va fi și mai senin prin tine, Nică” (Zarifopol-Illias, 2000, [71]). Desprinsă din mijlocul scrisorii, licărirea de speranță exprimată proverbial își disipează forța retorică, dar ne permite, totuși, să înțelegem că, la Eminescu, proverbul nu e valorificat mecanic, ca un desen imprimat pe un fond, ci e o discretă, dar eficientă cale de acces către meditația concisă. Acest stil de a contempla lumea prin ocheanul unui șirag de proverbe are o vechime care, în istoria culturală a umanității, pare a se confunda cu zorii scrisului, iar în literatura secolului al XIX-lea e prezent la scriitorii români admiraţi de Eminescu: Costache Negruzzi, Anton Pann, Ion Creangă. Astfel, în Povestea lui Harap-Alb (1877), cînd spînul îi poruncește eroului să aducă „sălăți” din Grădina Ursului, personajul principal dă fuga la grajd și începe a-și plînge de necaz, lamentîndu-se că rău a făcut de nu a luat în seamă sfaturile părintești. Mai tare din fire decît stăpînul său, calul năzdrăvan îl îmbărbătează pe Harap-Alb cu vorbe de duh: „- Stăpîne, ține-te bine pe mine, că am să bor lin ca vîntul, să cutrierăm pămîntul. Mare-i Dumnezeu și meșteru-i dracul. Hèlbet! Vom putè veni de hac și Spînului celuia, nu-i e vremea trecută" (Creangă, 1970, I, p. 93).

Dincolo de rezonanța paremiologică dintre scrisoarea eminesciană și basmul povestaşului moldovean, e demnă de interes tehnica de lucru cu proverbul. Valorificat în dialogul literar și în cel epistolar, proverbul devine emblema meșteșugului de a scrie fără asperități, ca și cum salba de cuvinte s-ar așterne spontan pe hîrtie, așa cum vorba răsare pe buzele omului. Grefată în ființa trudnică a scrisului, această himeră a oralității prelungește în literă ecourile rostirii. Citind, ai impresia că auzi un glas, că cel aflat la distanță-și în spațiu, şi în timp —îţi şoptește de peste umăr. În intimitatea scrisului epistolar eminescian, acest efect de anulare a distanței captează fluxul de conștiință, trăirea de moment, eliberarea electrizantă a gîndurilor în cuvinte și, prin acestea, dobîndește o mare intensitate afectivă, ca în următorul fragment:

\begin{abstract}
„Draga mea Veronicuţă,
Sînt cinci ceasuri de dimineață și eu, luîndu-mă cu lucrul, n-am putut închide ochii încă. Acum, după ce-am sfîrșit cîte aveam de făcut, închei ziua gîndind la tine, pasărea mea cea sprintenă, cea voioasă și tristă totodată aș vrea să pun mîna pe tine, să te sărut pe aripă... pe locul unde va fi fost odată două aripi, pe umărul tău cel alb și rotund și frumos. Dar trebuie să-mi pun pofta-n cui, căci în acest moment tu dormi dusă, în pătuțul aşternut desigur c-o fină pînză de in, iar eu mă uit în lumînare și gîndesc la tine. Dormi și nu te trezi, draga mea Nicuţă, că eu te păzesc tocmai de aici".
\end{abstract}

(Zarifopol-Illias, 2000, [43])

\title{
3. Rame proverbiale
}

Nu doar vorbirea și scrisorile poetului, ci și manuscrisele sale ne îndeamnă să credem că lumea proverbelor a suscitat un interes care nu poate fi strict circumscris sferei de preocupări legate de culegerea folclorului, ci, mai degrabă, reflectă travaliul enorm întreprins de Eminescu pentru a acomoda temperaturile înalte ale culturii savante la orizontul comun de lectură pe care îl presupun articolele de presă adresate unui public educat. De altfel, încă din epoca studenției, poetul, cititor devotat de ziare și reviste ${ }^{3}$, constată că stilul jurnalistic al timpului este, la Viena, un stil intelectual, infuzat cu referințe și aluzii livrești, și, prin aceasta, deosebit de retorica eclectică și imitativă a primelor valuri de ziare românești. La noi, scrisul gazetăresc se

\footnotetext{
${ }^{3}$ „Lectura ziarelor și revistelor germane a fost o ocupație permanentă a poetului și nu ceva întîmplător, și putem spune fără exagerare că a fost cu adevărat predominantă în formațiunea sa intelectuală. Faptul acesta nu e așa de surprinzător dacă luăm în considerație nivelul informativ și științific al periodicelor timpului, care puteau juca un rol mult mai important decît cele din zilele noastre, cînd există tot felul de alte mijloace de informare a maselor" (Frisch, 1999, I, p. 20).
} 
profesionalizează în a doua jumătate a secolului al XIX-lea, mai cu seamă între 1860-1880. În acest context, un scriitor cu extraordinare disponibilități experimentale, precum Eminescu, practică un repertoriu divers de rețete editoriale, de la știre la pamflet, de la anchetă la foileton. Prinsă în matricea mozaicată a textelor sale, plăcerea de a cultiva aforismul, aluzia, citatul, calamburul, maxima, proverbul, vorba de duh sau zicala ține de miezul incandescent al scrisului eminescian și a favorizat constatarea că scriitorul a făcut să înflorească pe teren jurnalistic virtuțile expresive ale limbii populare (Andriescu, 1979, p. 158). De fapt, stilul jurnalistic eminescian se dovedește, în istoria presei autohtone, un artefact inimitabil, o emblemă vie a cunoștințelor, viziunii despre lume și personalității scriitorului.

La Eminescu, proverbele au, dacă dăm importanță însemnărilor făcute pe durata studiilor la Universitatea din Berlin, valoare de etimon spiritual ${ }^{4}$. Considerate din unghiul etnopsihologiei, paremiile oglindesc felul de a fi al omului din popor: „Istețimea și înțelepciunea unui popor, spiritul de observație profund și ascuțit, caracterul destoinic, vorba de duh, fantezia și chiar umorul autentic, toate acestea se reflectă în proverb” (Eminescu, 1993, p. 639). Acceptînd că elementele sapiențiale populare pot dezvălui tușele unui portret al mentalului colectiv, în sensul că ar permite conturarea trăsăturilor de personalitate care alcătuiesc profilul psihologic al unei națiuni, Eminescu înscrie în triplă ramă-filozofică, etică și estetică—concepția sa asupra identității proverbelor.

În rama filozofiei stau considerațiile și comentariile care devoalează că un proverb este un fapt de cunoaștere încifrat în simbolurile unei limbi. Altfel spus, proverbul este o formă simplă de acces spre înțelepciune, în condițiile în care iubirea de înțelepciune, filozofia este, după cum notează scriitorul, „așezarea ființei lumii în noțiuni, spre a căror stabilire judecata nu se servește de altă autoritate decît de-a sa proprie” (Eminescu, 1993, p. 20). Miniaturile textuale numite proverbe sînt eșantioane de gîndire și de limbaj care surprind, aidoma instantaneelor fotografice, impresii și judecăți asupra unor secvențe din caleidoscopul realității (Norrick, 1985, p. 16). Forța lor de problematizare rezidă în tensiunea dintre amplitudinea cugetului și reliefurile realului, astfel că proverbele semnalează de pe poziţie critică ce raport se instituie între gîndire și evenimențial. Un proverb precum Si tacuisses philosophus mansisses, valorificat de Eminescu pe teren publicistic (Eminescu, 1984, p. 202; 1985, p. 30), propune un cadru de problematizare întemeiat, conform gramaticii adagiului, pe creditarea irealității: dacă ai fi tăcut, ai fi rămas filozof, dar acest lucru nu s-a întîmplat. Mai mult decît atît, concizia formală a proverbelor contrastează cu abisurile de înțeles pe care acestea le sondează. În consecință, lor nu li se poate atribui o anumită valoare de adevăr, ci, dimpotrivă, ele constituie relativizări care, în interiorul aceluiași ansamblu de reprezentări paremiologice, se pot situa în antiteză (Mieder, 1993, p. X).

Din cristalizarea și brevitatea formei decurg cîteva avantaje comunicative strategice. Ușor de memorat, lesne de folosit și facil de prelucrat, proverbele au mare potențial adaptativ, fiind frecvent solicitate să se lege de alte contexte decît cele în care ele au luat ființă; acest potențial angajează, deopotrivă, planul formei și planul înțelesului. Diversitatea uzului lămurește de ce proverbele nu sînt structuri fixe, așa cum, prea adesea, sîntem învăţaţi să credem, ci texte vii, care circulă în diverse medii de comunicare; prin urmare, ele înregistrează variație fonică, gramaticală și lexicală (Krikmann, 1985, p. 75).

În ramă etică poate fi pusă definirea proverbului ca ecuație morală. Prin dimensiunea lor didactică, de cuvinte de învățătură, proverbele conturează un spectru de calități și defecte omenești pe care le comentează din unghi tipologic. Tipurile umane înfățișate în proverbe, indiferent că se au în vedere cele puse în lumină pozitivă (omul cinstit, harnic, înțelept, sincer) sau cele zugrăvite în culori negative (omul fățarnic, leneș, nebun, mincinos), participă la alcătuirea unui model închegat empiric prin asemănări și deosebiri. Fiecare personaj paremiologic e schițat prin prisma unor situații-tip în care se manifestă calitatea sau defectul proverbial, așa că accentul e pus pe categoria pe care un individ oarecare din realitate ar putea-o ilustra atunci cînd alții discută despre el prin apel la formula sapiențială. Astfel, în proverbele românești, dar nu numai, leneșul e de regulă portretizat ca un om comod, indolent, sărac, viclean sau fără

\footnotetext{
${ }^{4}$ Conceptul, propus de Spitzer (1970, p. 54, 60), devoalează centrul vital intern al operei de artă. În prezentul studiu, noțiunea subliniază rolul proverbelor în portretizarea stereotipică a tipurilor omenești.
} 
cuvînt de onoare, în timp ce omul harnic e văzut ca un gospodar chibzuit, chivernisit, drept, milostiv sau serios. Între antipozi, lenea și hărnicia, încap, fără îndoială, și note intermediare, însă universul noțional și imagistic al proverbelor tinde mai degrabă către polarizări cît mai contrastante și mai lipsite de echivoc. Relațiile de asemănare și de contrast dintre unitățile constitutive ale unui sistem paremiologic, conceput ca o constelație de sfere conceptuale și textuale care se raportează unele la altele, pot fi gîndite și ca ecuații. Așa procedează Eminescu, atunci cînd notează că proverbele sînt ecuațiuni morale: „Ecuațiuni morale în proverb: Fiece om are bunul lui și răul lui. Bun, bun. Rău de bun. Chacun a les défauts de ses vertus et les vertus de ses défauts. Orice propensiune într-o parte corespunde c-o lipsă, c-o ridicare în cealaltă. Oare admirabilul discurs a lui Marc Anton nu cuprinde o ecuațiune? Oare orice calomnie fină, care începe prin a lăuda dușmanul, nu cuprinde o ecuațiune? Obiceiul lui Maiorescu. Oare teză și antiteză-la figuri și comparații-un vierme-n mare ce iubește-o stea—nu cuprinde o ecuațiune? Un vierme-n fundul mării înamorat de-o stea” (Eminescu, 1993, p. 330).

Însemnarea subliniază nu doar că un tip uman e zugrăvit prin punere în balanță cu alte tipuri, mecanism care justifică de ce aurea mediocritas jalonează cursul de gîndire, acțiune și comportament recomandat adesea în proverbe, ci și că, prin raportări contrastive, se pot naște asocieri paradoxale, cu cert potențial artistic. Un artist cu un atît de pronunțat simț al contrastelor, precum Eminescu, va fi remarcat ce resurse retorice redutabile pot fi maximele, aforismele și proverbele.

În rama estetică se cuvine prinsă interpretarea proverbului ca fapt literar și nu ca simplu act de comunicare. Este proverbul un obiect literar? Fără îndoială, da. Studiul istoric și filologic al producțiilor culturale ale civilizațiilor străvechi relevă că, încă din cele mai vechi timpuri, s-a constituit un gen distinct de scrieri numit de specialiști literatură sapiențială. În vechiul Sumer, acest corpus cuprindea cinci categorii de texte: a) proverbe; b) eseuri miniaturale; c) instrucțiuni și precepte; d) fragmente didactice și e) dispute și dezbateri (Kramer, 1951, p. 28). Alți specialiști au lărgit baza de texte, incluzînd în cîmpul literaturii sapiențiale și fabula, ghicitorile, parabola, sau satira (Gordon, apud Murphy, 1981, p. 9). Primele proverbe despre care învățații au știință precisă datează de mai bine de patru milenii și jumătate. Conform inscripțiilor de pe tăblițele de lut imprimate cu scriere cuneiformă, limba sumeriană, cea mai veche limbă scrisă a umanitătiii, pare să fi ieșit din uz în mileniul al doilea î.Hr., fiind concurată de akkadiană, o limbă semitică înrudită cu ebraica, siriaca și araba. Sutele de proverbe scrise în sumeriană, mai întîi, și în akkadiană, mai apoi, sînt cele mai vechi texte literare din lume. Ele erau folosite în educația scribală și, prin conținut, reflectă modul de viață și viziunea despre lume a sumerienilor (Alster, 1997, I, p. xix). La fel de importantă ca dubla lor origine, populară și cultă, este seria de trăsături expresive proprii astăzi paremiilor, maximelor și adagiilor: lapidaritatea, uzul generic al persoanei gramaticale, paralelismul și prezența procedeelor expresive specifice proverbelor: metafora, ironia, comparația, hiperbola, metonimia și sinecdoca (Gordon, 1968, p. 10-20).

$\mathrm{Cu}$ fondul literar al Mesopotamiei antice rezonează și unele din cărțile Bibliei, incluse de specialiști în sfera literaturii sapiențiale ${ }^{5}$ (Murphy, 1981, p. 3). De altfel, merită subliniat că Scriptura reprezintă una din marile surse de proverbializare în lumea creștină. În Europa, acestui izvor i se adaugă încă trei mari căi de diseminare paremiologică: a) împrumutul de la un popor la altul, b) latina medievală și c) literatura clasică greco-latină (Mieder, 2004, p. 10-13). Tezaurul de proverbe al fiecărui neam creștin include între 300 și 500 de proverbe de origine biblică (Mieder, 1990, p. 12). Dacă adăugăm că moștenirea paremiologică a antichității s-a conservat în marile florilegii medievale și renascentiste de proverbe și adagii, fiind mai apoi folclorizată în multe culturi, grație largii circulații a unor compilații precum Floarea darurilor, este limpede că fascinația lui Eminescu pentru străvechea literatură a proverbelor oglindește intuiția că, prin mijlocirea acestor texte miniaturale, se poate accesa și restaura o viziune arhaică asupra lumii. Pentru poet, universul proverbelor este situl arheologic în care pot fi căutate vestigiile literare ale unei vechi gîndiri pierdute.

$\mathrm{Cu}$ acest temei, glosarul eminescian de proverbe și construcții idiomatice publicat în ediția magna

\footnotetext{
${ }^{5}$ Sintagma literatură sapiențială s-a cristalizat mai întîi în studiile de biblistică, fiind apoi fructificată și pentru a denumi cîteva categorii de texte din literatura Mesopotamiei antice. În studiile închinate cărților sapiențiale ale Scripturii, în principal Iov, Proverbele și Ecleziastul, unii cercetători disting existența a două genuri literare: 1. zicala, cu trei specii: proverbul, zicala empirică și zicala didactică sau cultă; 2. ordine și interdicții (Murphy, 1981, p. 3-6).
} 
inițiată de Perpessicius (Eminescu, 1963, p. 363-381) trebuie văzut mai puțin ca dovadă a eforturilor scriitorului de a culege nestematele înțelepciunii populare și mai mult ca travaliu în șantierul în care poetul a încercat să restaureze, atît pentru nevoi de lucru proprii, cît și pentru valoarea lor estetică, piese sapiențiale de circulație românească. Un bun sprijin în favoarea acestei ipoteze îl constituie chiar glosarul compilat de Eminescu, în care mai toate din cele aproape 400 de unități paremiologice și frazeologice sînt decupate din marele infoliu de pilde al vornicului Iordache Golescu ${ }^{6}$, cărora li se adaugă tăieturi din culegerea de proverburi a lui Anton Pann, cunoscută și sub numele Povestea vorbii. Cu alte cuvinte, poetul a stilizat filonul cult, țintind să confere unor eșantioane livrești masca de element popular.

\section{Proverb și stil în textul jurnalistic eminescian}

Pentru a înțelege cum fructifică gazetarul decupajele extrase din cărți pentru a le conferi aură folclorică putem lua ca exemplu articolul de fond publicat în ziarul Timpul din 31 octombrie 1879. În acest text, în care redactorul-poet polemizează cu gazetele liberale Românul și Presa pe tema procesului de răscumpărare a căilor ferate, sînt inserate bucăți deja decupate și copiate în caietul de lucru, ca și cum, în momentul redactării articolului, Eminescu ar fi avut glosarul înaintea ochilor și ar fi ales cu migală de artist piesele proverbiale potrivite pentru mozaicul său textual:

„Abia apucarăm să zicem că în principiu conservatorii nu sînt contra răscumpărării si îndată atît „Românul” cît și organul personal al marelui om de stat s-acățară de acest pai pentru a deduce monstruozitatea că aprobăm proiectul de răscumpărare. Milă de silă și dor de zor (s.n., I.M.), adecă, vrem nu vrem, ne apucă d-lor pe dinainte și ne spun că voim chiar proiectul cum este el. Să ne permită însă atît organul agenților rusești cît și acela al marelui om de stat să le spunem că una e una și două fac mai multe (s.n., I.M.). Pentru răscumpărare în principiu a fost cabinetul Lascar Catargiu, ba daca marele om de stat d. Vasile Boerescu va binevoi a-şi aduce aminte cauza pentru care cinstit d-sa a ieșit din cabinet, atunci organul marelui om de stat va vedea lesne c-a zburat pentru că d-sa voia să facă din răscumpărare un gheșeft, ceea ce bătrînul Lascar Catargiu nu voia cu nici un chip.

În fine, ce mai la deal la vale, lucrul stă astfel. Sub cabinetul Catargiu încă acționarii, amăgiți şi ei de d. dr. Stroussberg și de Pătărlăgenii şi Costineștii noștri, precum era amăgit și poporul românesc, și încărcați de multele datorii ce au trebuit să le contracteze pentru a mîntui drumurile de fier, propun guvernului conversiunea acțiilor în titluri de ale statului și trecerea drumului de fier în proprietatea statului. Conversiunea făcută în mod echitabil, adică purtînd acționarii pierderile rezultate din călcarea contractului, putea să fie bună pentru țară, nu din cauza foloaselor materiale, cari, fiind tranzacțiunea dreaptă și echitabilă, nu puteau fi însemnate, ci din cauza folosului moral că statul, devenind proprietar al drumului de fier, ar fi deschis calea la o mulțime de lume de a noastră să-nvețe lucruri practice, și cu temei, să se ocupe de șine și mașine cu vapor în loc de pișecherlîc politic și blagomanii nesărate de gazetărie.

Adică lucru cinstit era din capul locului și nici putea să fie altfel de vreme ce un om de țară, care nici nu-i advocat măcar, avea s-o puie la cale.

$\mathrm{Nu}$ asta însă era marelui om de stat.

Repede fondează Banca de București cu scopul anume de a cumpăra d-sa acții și de a le vinde statului apoi cu 300 la sută cîștig, fiind marele om de stat ministru de esterne.

Atunci i s-a dat să înțeleagă, c-un cusur subțire nu-i vorbă, căci marele om de stat e dintre obrazele subțiri cari se țin cu cheltuială (s.n., I.M.) —că nu poate fi și Bancă de București și ministru totdeodată, de aceea să aleagă între două.

${ }^{6}$ Titlul complet al lucrării este Pilde, povățuiri i cuvinte adăvărate și povești adunate dă dumnealui dvornicul Iordache Golescul, ful răposatului banul Radul Golescul (ms. 213, cf. CMR, I, 62). 
D-sa a preferat apoi Banca de București și a trecut în opoziție. Din momentul în care ca ministru și gheșeftar totodată nu mai putea face răscumpărarea, erau compromise libertatea, naționalitatea și toate celelalte substantive abstracte. (...).

Așadar, ca să nu ne uităm vorba, Banca de București a fost mofluză ca nepusă în masă. De-acolo „centru”, de-acolo unirea cu roșii, cu cari totul e cu putință, de-acolo „naţionalitate, libertate, dreptate” în „Românul” care, în loc de „Luminează-te și vei fi”, ar fi trebuit să înscrie maxima d-lui Buescu: „Mai aproape dinții decît părinții” (s.n., I.M.).

De aceea noi, în principiu pentru răscumpărare, facem din răscumpărare o cestiune de încredere. Am avut deja Banca de București în Consiliul de Miniștri, nu mai voim s-o vedem și astăzi. Conservatorii au avut întîi „răscumpărarea” în programa lor, încît noi sîntem nașii și „naşul botează, naşul cutează" (s.n., I.M.).

O spunem deci din esperiență că e gheșeft la mijloc, gheșeft infect, gheșeft à la Banca de București. (...).

Precedentul frumos al Băncii de București ne face într-adevăr să nu dăm crezare argumentaţiunii încifrate a guvernului, pe care voim s-o descifrăm ca să nu iasă din ea negustoria lui Nastratin (s.n., I.M.). Pe lîngă statul proprietar rămîn ca proprietari toți aceia cari vor prefera a-și ținea acțiile și a-și lua dividentele în curs de nouăzeci de ani. Acești oameni vor putea fi membri în adunarea generală, membri în reprezentațiunile acestor adunări, c-un cuvînt vor avea parte la toate: şi din coş grăunțe și din fäină parte și din traistă merinde (s.n., I.M.), adecă cuiul lui Pepelea în casa românului. (...).

De aceea-considerînd elementele din cari sînt compuşi roșii și împrejurarea agravantă a fostei Bance de București-repetăm că facem din încredere cestiunea principală. Răscumpărarea, ieri rea şi azi bună, nu prea încape în mintea omului. Apoi mai știm că nici diavolul biserici face (s.n.), nici roșii au adus vrun bine în țara aceasta, încît îndărătul răscumpărării s-ascunde, după chiar opinia d-lui Dim. Sturza, propuitorul, un dezastru financiar”.

(Eminescu, 1989, p. 341-343)

În culegerea poetului, șiragul de proverbe, zicale și aluzii proverbiale din acest articol relevă ordinea în care au fost extrase din marele infoliu al lui Iordache Golescu ${ }^{7}$. Între unitățile înregistrate în ediția de Opere, cu numere de la 339 la 349, regăsim textele Mai aproape dinții ca părinții (339), Milă de silă, dor de zor (340), Dracul nu face biserici (345) și Și din coş grăunțe, și din postavă tărîțe, și din făină parte și din traistă merinde (349). Un alt decupaj proverbial, Una-i una, două mai mult, figurează cu numărul 108: ordinea din glosar arată că acestea au fost copiate pe sărite din manuscrisul-sursă. De exemplu, unităţile numerotate de la 1 la 116 sînt preluate din „Pilde i tîlcuirea lor” (Golescu, 1990, p. 165-176), iar unitățile numerotate de la 285 la 316 sînt extrase din capitolul „Pentru om” . O altă vorbă înaripată, negustoria lui Nastratin, inventariată cu numărul 358, preluată fie din antologia lui Golescu, fie de la Anton Pann, este utilizată în mai multe articole.

Prin includerea în partea introductivă a articolului, elementul paremiologic Milă de silă, dor de zor primește rolul de a ațița focul polemic, servind ca element prin care se amorsează argumentația. Zicala Una e una și două fac mai multe întărește legitimitatea punctului de vedere exprimat de jurnalist, înfățişat ca „Voce” a comunității. Prelucrarea aluzivă a proverbului Obrazul subțire cu mare cheltuială se ține are ca rost prefacerea paremiei în ferment de caracterizare ironică, personajul creionat în articol, demnitarul Vasile Boerescu, fiind înfățișat în culorile tipurilor umane din lumea proverbelor, ca un om duplicitar și risipitor. Invocate pe terenul vieții politice, subînțelesurile nupțiale ale proverbului Naşul botează, naşul cutează au rostul de a afirma superioritatea viziunii virile a conservatorilor asupra programului liberal. De

\footnotetext{
${ }^{7}$ Pentru prezentarea istorică a împrejurărilor în care Eminescu a ajuns în posesia acestui manuscris cu pilde, povățuiri și povești se poate consulta Perpessicius (1954, p. 27-28), reluat în Golescu (1990, p. 369-375).

${ }^{8}$ Fără a fi editată în întregime, culegerea vornicului Golescu a fost în mare parte transcrisă de Iuliu Zanne și inclusă în volumele VIII și XI ale seriei sale de proverbe românești, în vreme ce alte părți au fost editate mult mai tîrziu.
} 
Ioan Milică

altfel, măsurile luate de liberali sînt considerate ca ilustrări tipice ale corupției și lăcomiei, aspect reliefat prin recurs la formula și din coş grăunțe și din fäinăparte și din traistă merinde. Conturată de la bun început și augmentată retoric pe parcursul demonstrației, concluzia că răscumpărarea căilor ferate se va dovedi un dezastru financiar este, în încheiere, intensificată prin metaforizare paremiologică. Demonizarea guvernării liberale, „nici diavolul biserici face, nici roșii au adus vrun bine în țara aceasta”, este, fără îndoială, un artificiu stilistic menit să placă publicului conservator al ziarului. În această secvență, folosirea proverbului joacă rolul expresiv de a întări concluziv adeziunea cititorului faţă de punctul de vedere exprimat în articol.

Pe de o parte, între opinia exprimată de gazetar și înțelesurile proverbelor se creează un paralelism generator de reverberații, ca și cum formula sapiențială ar deveni clopotul din care răsună ecoul celor afirmate de jurnalist. Pe de altă parte, prin apelul la cuvintele de înțelepciune cu izvor livresc, gazetarul creează un efect de oralitate țărănească arhaică, iar această tehnică de seducere a cititorului are fundament poetic, în sensul că articolul de ziar, deși constituie o compunere de factură cultă, atît prin structură, cît și prin limbaj, e șlefuit în aşa fel încît să redea ritmurile și sclipirile vorbirii populare. Mizanscena oglindește atenția acordată formei în care este înveșmîntat conținutul mesajului și concordă cu mărturia lui Ion Slavici despre eforturile depuse de Eminescu pentru a face ca noțiunile și imaginile înflorite din cuvinte să pară dăltuite în marmura frumoasă și curată a limbii poporului:

„La dînsul această potrivire cu felul poporal era voită dinadins. Pe cînd alții, cum erau Creangă, Ispirescu ori Sima al lui Ioan, au scris în genul poporal fiindcă, ieșiți din mijlocul poporului, rămăseseră țărani cu oarecare cultură și nu erau în stare să scrie altfel, Eminescu, care nu era ieșit din mijlocul poporului ținea să se potrivească întru toate cu poporul pentru că numai așa putea să străbată şi să rămîie”.

(Slavici, 1998, p. 47)

Avînd dovada că glosarul paremiologic eminescian e, în primul rînd, un instrument pus la lucru mai cu seamă pe terenul activității gazetărești, motiv pentru care a și fost folosit de specialiști pentru a stabili paternitatea unor articole, nu ne mai rămîne decît să observăm cum pledează Eminescu în favoarea înțelegerii proverbului ca vechi simbol identitar. O devoalare a înțelegerii proverbelor ca eșantioane de gîndire și artă populară aflăm într-un articol publicat la 5 ianuarie 1877, în Curierul de Iaşi. Comentînd apariția, la Piatra Neamț, a unei foi literare, Colectorul literar pentru ambele sexe, Eminescu respinge moda traducerii lucrărilor literare „de o valoare îndoielnică” și susține necesitatea de a culege literatura populară, întrucît aceasta oglindește simțul lingvistic și artistic al poporului:

„Foi literare în provincie ar putea să facă un serviciu nemăsurat literaturei și lexiconului român. Limba de rînd a ziarelor politice amenință a îneca, ca buruiana rea, holda limbei vie a poporului. Afară de aceea, cu propășirea realismului modern, se șterg legende și povești, proverbe și locuțiuni, adevărate nestimate ale gîndirei poporului românesc. Dacă acele foi ne-ar da icoana locului prin culegerea exactă a formelor caracteristice ale gîndirei poporului, ele ar fi neprețuite. Dar traduceri din franțuzește sau din nemțește a unor producte nesănătoase? Cui folosesc? Ele întăresc numai ideea falsă că poporul în două mii de ani n-a avut nici limbă și cugetare și că aceste două trebuiesc plăsmuite în mod meșteșugit de către o anume academie”.

(Eminescu, 1980, p. 298-299)

Întrezărim în fragment atît considerarea proverbelor ca forme de cugetare și de limbaj caracteristice „gîndirei poporului", cît și înțelegerea lor ca vechi nestemate literare. Pledoaria poetului pentru conservarea acestor vestigii ale mentalului colectiv este animată de credința că modernitatea grăbește căderea în uitare a formelor lingvistice și literare de tip arhaic și întreține, astfel, alienarea omului modern. Salvarea memoriei culturale a trecutului ar echivala, așadar, cu o binefăcătoare întoarcere la matca tradiției. Zestrea de „locuțiuni, proverbe, cîntece și povești” constituie o „minunată operă” la care au contribuit „milioane de capete, în mare parte foarte bine formate, și zeci de cărturari cu bun-simț și cu auz credincios" (Eminescu, 
1989, p. 84). În antiteză cu această comoară luminată, prezentul revarsă, în opinia gazetarului, o avalanșă de elemente cosmopolite, străine de felul de a gîndi al poporului, aşa că surghiunirea lor din uzul cotidian se impune ca datorie a spiritelor educate. De aceea, articolul de presă se cuvine conceput și citit ca poveste a vorbei, ca viu spectacol de idei și de cuvinte opus limbajului uscat și cosmopolit al gazetarilor și politicienilor fără idei, fără imaginație și fără verb. În fond, ziarul este o lume de hîrtie, iar peste acest imperiu al literei scriitorul domnește, încă, suveran.

\section{Bibliografie}

Alster, B. (1997). Proverbs of the Ancient Sumer, The World's Earliest Proverb Collections, 2 vol., CDL Press, Bethesda, Maryland. Andriescu, Al. (1979). Limba presei românești în secolul al XIX-lea, Editura Junimea, Iași.

Cartojan, N. (1974). Cărțilepopulare în literatura românească, vol. I. Epoca influenței sud-slave, Editura Enciclopedică Română, București.

Cioabă, C. (ed.) (2013). Mărturii despre Eminescu, Editura Humanitas, București.

CMR = Ștrempel, G. (1978). Catalogul manuscriselor românești. B.A.R. 1-1600, vol. I, Editura Științifică și Enciclopedică, București.

Creangă, I. (1970). Opere, ediție îngrijită de Iorgu Iordan și Elisabeta Brâncuș, vol. I, Editura Minerva, București.

Eminescu, M. (1963). Opere, vol. VI, Literatura populară. Introducere - Poeme originale de inspirație folclorică - Lirica populară - Balade - Dramatice - Basme in proză - Irmoase - Paremiologie - Note și variante - Anexe - Exerciții \& Moloz - Caetul anonim - Bibliografie - Indices, Editura Academiei R.P.R., București.

Eminescu, M. (1980). Opere, vol. IX, Publicistică, 1870-1877, „Albina”, „Familia”, „Federațiunea”, „Convorbiri literare”, „Curierul de Iaşi”, Editura Academiei R.S.R., București.

Eminescu, M. (1984). Opere, vol. XI, Publicistică, 17 februarie - 31 decembrie 1880, „Timpul”, Editura Academiei R.S.R., București.

Eminescu, M. (1985). Opere, vol. XIII, Publicistică, 1882-1883, 1888-1889, „Timpul”, „România liberă”, „Fîntîna Blanduziei”, Editura Academiei R.S.R., București.

Eminescu, M. (1989). Opere, vol. X, Publicistică, I noiembrie 1877 - 15 februarie 1880, „Timpul”, Editura Academiei R.S.R., București.

Eminescu, M. (1993). Opere, vol. XV, Fragmentarium. Addenda ediției, Editura Academiei Române, București.

Frisch, H. (1999). Sursele germane ale creației eminesciene, 2 vol., Editura Saeculum I.O., București.

Georgescu, M. (ed.) (1997). Archirie și Anadan, în Gheție, I. \& Mareș, Al. (coord.), Cele mai vechi cărți populare în literatura română, vol. II, Editura Minerva, București, 1997, p. 103-169.

Golescu, I. (1973). Proverbe comentate, ediție îngrijită de dr. Gh. Paschia, colecția Cogito, Editura Albatros, București.

Golescu, I. (1990). Scrieri alese, ediție coordonată de Al. Rosetti, Editura Cartea Românească, București.

Gordon, E.I. (1968). Sumerian Proverbs: glimpses of everyday life in ancient Mesopotamia, Greenwood Press Publishers, New York.

Kramer, S.N. (1951). Sumerian Wisdom Literature: A Preliminary Survey, în „Bulletin of the American Schools of Oriental Research", 122, p. 28-31, Crossref.

Krikmann, A. (1985). Some Additional Aspects of Semantic Indefiniteness of Proverbs, în „Proverbium. Yearbook of International Proverb Scholarship", The Ohio State University, 2, p. 58-85.

Mieder, W. (1990). Not by Bread Alone. Proverbs of the Bible, Shelburne, Vermont, The New England Press.

Mieder, W. (1993). Proverbs are Never out of Season. Popular Wisdom in the Modern Age, Oxford University Press, Oxford.

Mieder, W. (2004). Proverbs: a handbook, Westport, Connecticut, London, Greenwood Press.

Muntean, G. (ed.) (1984). Proverbe româneşti, Editura Minerva, București.

Murphy, R.E. (1981). Wisdom Literature. Job, Proverbs, Ruth, Canticles, Ecclesiastes, and Esther, William B. Eerdmans Publishing Company, Grand Rapids, Michigan.

Norrick, N. (1985). How Proverbs Mean: Semantic Studies in English Proverbs, Mouton, New York, Crossref.

Oprea, Al. (1983). In căutarea lui Eminescu gazetarul, Editura Minerva, București.

Pann, A. (1963). Scrieri literare, 3 vol., Editura pentru literatură, București.

Perpessicius (1954). Opera folcloristică a lui Iordache Golescu, în „Studii și cercetări de istorie literară și foclor”, vol. III, Editura Academiei R.P.R., București.

Perpessicius (1983). Eminescu şi folclorul, în „Eminesciana”, Editura Junimea, Iaşi.

Slavici, I. (1998). Amintiri, Editura Viitorul Românesc, Deva.

Spitzer, L. (1970). Études de style, Gallimard, Paris.

Ștefanelli, T. (1914). Amintiri despre Eminescu, Institutul de Arte Grafice C. Sfetea, București.

Zanne, I. A. (1895-1903). Proverbele românilor din România, Basarabia, Bucovina, Ungaria, Istria și Macedonia, București.

Zarifopol-Illias, C. (ed.) (2000). Dulcea mea Doamnă / Eminul meu iubit. Corespondență inedită Mihai Eminescu - Veronica Micle, Editura Polirom, Iași. 